\title{
Multiplex nested polymerase chain reaction for Treponema pallidum using blood is more sensitive than using serum
}

Ida Effendi*,**, Yeva Rosana**, Andi Yasmon**, and Wresti Indriatmi***

\begin{abstract}
\section{BACKGROUND}

Syphilis is a multistage disease transmitted primarily through sexual intercourse. Nowadays, the polymerase chain reaction (PCR) test for Treponema pallidum has been widely used and is expected to overcome problems in diagnostic tests for syphilis. The Treponema pallidum PCR is influenced by type of specimens, PCR methods and target genes. This study aimed to assess the use of blood and serum in multiplex nested PCR for Treponema pallidum, targeting the $23 \mathrm{~S}$ rRNA.
\end{abstract}

\section{METHODS}

A cross-sectional study was conducted from April 2015 - April 2016. Sampling was carried out consecutively among patients with clinical features of secondary syphilis who came to Sexually Transmitted Disease (STD) clinics in Jakarta. All sera were also tested with Rapid Plasma Reagin (RPR) and Treponema pallidum Hemagglutination Assay (TPHA) assay, which was considered as the gold standard for this study. We determined the sensitivity and specificity of the multiplex nested PCR for Treponema pallidum using blood and serum.

\section{RESULTS}

PCR test was performed on 122 clinical specimens ( 61 blood and 61 serum). The positive results of PCR test on blood was $22.95 \%$ and serum was $6.56 \%$, while the positive results of serology was $68.85 \%$. The sensitivity of Treponema pallidum multiplex nested PCR on blood was 30.95\% compared to serum $9.52 \%(p=0.006)$. PCR test on blood is able to detect 3.25 times higher than serum.

\section{CONCLUSION}

The use of blood has a higher proportion of positives compared to serum in Treponema pallidum multiplex nested PCR using 23S rRNA target gene.

Keywords: Secondary syphilis, Treponema pallidum, multiplex nested PCR test, blood, serum
*Department of Microbiology,

Faculty of Medicine, Trisakti

University

**Department of Microbiology,

Faculty of Medicine, University of

Indonesia

*** Department of

Dermatovenereology, Cipto

Mangunkusumo Hospital

\section{Correspondence:}

dr. Ida Effendi, SpMK

Department of Microbiology,

Faculty of Medicine,

Trisakti University,

Jl. Kyai Tapa 260, Jakarta 11450,

Indonesia

Phone: +6221 5672731

Fax: +6221 5660706

Email: idaeffendi@trisakti.ac.id

Date of first submission, February 6,

2018

Date of final revised submission, April 19, 2018

Date of acceptance, April 19, 2018

This open access article is distributed under a Creative Commons Attribution-

Non Commercial-Share Alike 4.0

International License

Cite this article as: Effendi I, Rosana Y, Yasmon A, et al. Multiplex nested Polymerase Chain Reaction for Treponema pallidum using blood is more sensitive than using serum. Univ Med 2018;37:7584. doi: 10.18051/UnivMed.2018.v37. $75-84$ 


\section{INTRODUCTION}

Syphilis is one of the multistage diseases that are transmitted mainly through sexual intercourse. This disease shows diverse clinical manifestations, a protracted course, and serious complications. Syphilis constitutes a global health problem particularly in developing countries, including Indonesia. ${ }^{(1)}$

Since this disease was first known in the fifteenth to twentieth centuries, the prevalence of syphilis had already decreased, but in the last few decades, the incidence of early syphilis in various countries in America, Europe, and Asia was reported to be again on the increase. ${ }^{(1,2)} \mathrm{In}$ Indonesia, based on a survey conducted by the Integrated Surveillance of Behavioral Biology program (Surveilans Terpadu Biologi Perilaku, STBP) in the years 2007 and 2011 on the population most at risk, there was an increase in the prevalence of syphilis. ${ }^{(3)}$ This occurred particularly in the population most at risk, i.e. males who had sexual intercourse with males (MSM), from a prevalence of $4 \%$ in 2007 to $13 \%$ in 2011. The highest prevalence of syphilis was found in the transvestite population, i.e. a total of $28 \%$. $^{(3)}$ According to data from the WHO in 2008, the prevalence of syphilis in Southeast Asian countries was 12.3 million, i.e. 6.2 millions in women and 6.1 millions in males. ${ }^{(4)}$ In 2012, WHO estimated that there were 6 million new cases of syphilis each year in the whole world and most cases occurred in developing countries. ${ }^{(5)}$

The diagnosis of syphilis is established based on anamnesis, physical examination of the patient and accessory examination. The difficulty in diagnostic testing of syphilis is due to the fact that Treponema pallidum cannot be cultured in vitro. ${ }^{(6,7)}$

Microscopic examination may directly evaluate the presence of Treponema pallidum, but requires a special microscope or special staining, and cannot differentiate between Treponema species. At present, laboratory facilities for microscopic examination of syphilis are very limited. In addition, experienced laboratory technicians are required to evaluate Treponema pallidum by microscopy. Serologic tests are diagnostic tests for syphilis that are commonly used, including in Indonesia. The extremely sensitive nontreponemal tests are followed by the more specific treponemal confirmatory tests. However, there are several limitations in nontreponemal or treponemal tests, as they may show false positive, false negative, or dubious results.

At present, the polymerase chain reaction (PCR) for Treponema pallidum is widely used and is expected to be able to decrease the problems in diagnostic testing of syphilis. The published studies on the Treponema pallidum PCR test comprise conventional PCR, real-time PCR, nested PCR and multiplex PCR, with various target genes specific for Treponema pallidum, such as the target genes PolA, tpp47, and $b m p$.

At present, the PCR methods have become the diagnostic tests recommended by the CDC and the United Kingdom for detecting Treponema pallidum, in addition to microscopy. ${ }^{(8,9)}$ The Treponema pallidum PCR test may use various types of clinical specimen depending on the course of the disease. The sensitivity and specificity of the molecular PCR test results are affected by the type of specimen, the PCR method, and the target gene used. ${ }^{(10,11)}$

Specimens that may be used for the Treponema pallidum PCR test in secondary syphilis are exudates from syphilitic lesions and blood. The sensitivity of PCR with smears from lesions of secondary syphilis reaches $80 \%$ and the specificity $98.6 \% .^{(12)}$ The skin lesions in secondary syphilis are extremely infectious. However, not all patients with secondary syphilis show skin lesions; in addition, sample collection from skin lesions of patients with secondary syphilis is more difficult, invasive, and causes discomfort in the patients.

Blood is the specimen that may used for examination in all stages of syphilis. The number of Treponema pallidum in the blood is highest in 
early syphilis. ${ }^{(13,14)}$ In addition to the complete set of blood components (whole blood), other blood components may also be used as specimen for the Treponema pallidum PCR, such as serum, plasma, and peripheral blood mononuclear cells (PBMC). Cruz et al. ${ }^{(13)}$ found that blood is the best type of specimen for detecting Treponema pallidum.

Grange et al. ${ }^{(10)}$ reported on the higher proportion of positives for blood as compared with serum, plasma, and PBMC for nested PCR testing in secondary syphilis. In contrast to that reported by Cruz et al. ${ }^{(13)}$ and by Gayet-Ageron et al. ${ }^{(15)}$ reported that serum was better than blood for detecting Treponema pallidum using PCR in secondary syphilis ( $47 \%$ and $36 \%)$.

The difference between the results of Cruz et al. ${ }^{(13)}$ and Grange et al. ${ }^{(10)}$ on the one hand and Gayet-Ageron et al. ${ }^{(15)}$ on the other, is thought to be due to factors of the PCR test system used, such as difference in target gene and primer design.

The purpose of $23 \mathrm{~S}$ rRNA with the multiplex nested PCR method is to detect two-point mutations causing Treponema pallidum resistance to azithromycin, one of the alternative drugs of choice for syphilis. ${ }^{(16)}$ Therefore this study uses multiplex nested PCR to determine the better specimen between blood and serum for the application of this test.

\section{METHODS}

\section{Research design}

A cross-sectional study was performed from April 2015 to April 2016.

\section{Study subjects}

The study subjects were screened with consecutive methods, i.e. patients aged $>18$ years with the clinical picture of secondary syphilis who attended the Dermatoveneorology polyclinic in Cipto Mangunkusumo Hospital, the Sexually Transmitted Disease (STD) clinic of the Pasar Rebo subdistrict Puskesmas, the STD clinic of the Tambora subdistrict Puskesmas and the
Indonesian Familty Planning Association (Perkumpulan Keluarga Berencana Indonesia, PKBI) ProCare clinic. Patients who had received treatment were excluded from the study.

\section{Sample size determination}

The sample size was obtained by considering the proportion of positives of the PCR test with blood samples of secondary syphilis to be $38 \%$. $^{(10)}$ The sample size determination used the following formula:

$\mathrm{n} 1=\mathrm{n} 2=\left[\frac{(\mathrm{Z} \alpha \sqrt{2 \mathrm{PQ}})+(\mathrm{Z} \beta \sqrt{\mathrm{P} 1 \mathrm{Q} 1+\mathrm{P} 2 \mathrm{Q} 2})}{(\mathrm{P} 1-\mathrm{P} 2)^{2}}\right]^{2}$

where $\mathrm{n} 1=\mathrm{n} 2=$ sample size

$\mathrm{Z} \alpha=1.96$

$\mathrm{Z} \beta=0.842$

$\mathrm{P} 1=$ proportion of standard effect 1

P2 = proportion of investigated effect (clinical judgment)

[proportion of positives ]

$\mathrm{P}=1 / 2(\mathrm{P} 1+\mathrm{P} 2)$

$\mathrm{P} 2=38 \%=0.38$

$\mathrm{Q} 2=1-\mathrm{P} 2=0.62$

$\mathrm{P} 1-\mathrm{P} 2=25 \%=0.25$

$\mathrm{P} 1=0.63$

$\mathrm{Q} 1=0.37$

$\mathrm{P}=0.50$

$\mathrm{Q}=0.5$

so that the minimal sample size was 61 per group.

\section{Intervention}

From all patients, blood was drawn from the vein in the cubital fossa into two vacutainer tubes using sterile $23 \mathrm{G} 1 / 4$ inch needles. The blood was drawn to a volume of 3-4 $\mathrm{ml}$ into the red-capped tube without anticoagulant and to a volume of 1$2 \mathrm{ml}$ into the violet-capped tube containing EDTA anticoagulant. The blood in the tube without anticoagulant was processed into serum, which was used for the RPR and TPHA serological tests. Whole blood and serum were used for Treponema pallidum multiplex nested PCR testing. 


\section{Measurements}

The RPR and TPHA tests were performed quantitatively to determine the titration concentrations. The serological test results in patients with the picture of clinical secondary syphilis were considered to be positive if an RPR titer of $>1: 8$ and a TPHA titer of $>1: 80$ were obtained. A positive Treponema pallidum multiplex nested PCR test was shown by a 187bp band on visualization in 3\% agarose gel after electrophoresis at 100 volts for 30 minutes, as internal control indicating the presence of Treponema pallidum. If bands of $130 \mathrm{bp}$ and $100 \mathrm{bp}$ were also found, these show the presence of mutations at 2 points in the DNA sequence of azithromycin-resistant Treponema pallidum.

\section{Laboratory analysis}

Qualitative RPR testing used a commercial kit (RPR AIM Cat. No. E RPR 2) on the sera of all patients according to the protocol of the kit. The results that were reactive on qualitative RPR testing were to be followed with the quantitative RPR test. All samples subjected to the RPR test were confirmed with the quantitative TPHA (TPHA AIM Cat. No.TPHA E 100) according to the protocol of the kit.

The PCR test used the DNA resulting from the extraction of blood and serum that were stored at a temperature of $-35^{\circ} \mathrm{C}$. Blood was extracted according to the protocol of the Roche kit (High Pure PCR DNA Template Preparation Kit). Serum was extracted according to the protocol of the Qiagen kit (Qiagen QIAmp DNA mini kit). The multiplex nested PCR test used Treponema pallidum $23 \mathrm{~S}$ rRNA target genes and was already optimized using 3 (three) pairs of primers. ${ }^{(16)}$ The PCR 1 reaction used one pair of primers (forwardreverse) for detecting the $23 \mathrm{~S}$ rRNA component of Treponema pallidum. The reaction mixture with total volume of $20 \mu \mathrm{l}$ consisted of distilled water (DNase-free water) $7.5 \mu 1,10 \mathrm{x}$ HotStar PCR buffer $2.0 \mu 1,25 \mu \mathrm{M} \mathrm{MgCl}_{2} 0.2 \mu 1,10 \mu \mathrm{M}$ dNTP mix $0.4 \mu 1,5 x$ Q solution $4.0 \mu 1,10 \mu \mathrm{M}$ PCR1 F primer $0.4 \mu 1,10 \mu \mathrm{M}$ PCR1 R primer 0.4 $\mu 1$, and HotStar DNA polymerase enzyme $0.1 \mu 1$.
A volume of $5 \mu 1$ DNA was introduced to the reaction mixture as template. The PCR 1 reaction consisted of a total of 25 cycles at a predenaturation temperature of $95^{\circ} \mathrm{C}$ for $15^{\prime}$, denaturation at $95^{\circ} \mathrm{C}$ for $30^{\prime \prime}$, annealing at $58^{\circ} \mathrm{C}$ for $30^{\prime \prime}$, elongation at $72^{\circ} \mathrm{C}$ for $30^{\prime \prime}$, and final extension at $72^{\circ} \mathrm{C}$ for $10^{\prime}$.

The PCR 2 reaction used two pairs of primer (forward-reverse) with the purpose of amplifying the DNA sequence of Treponema pallidum where there are mutation points to identify azithromycin-resistant Treponema pallidum based on the mutation patterns of adenine bases into guanine in the DNA sequence positions 2058 and 2059 of the $23 \mathrm{~S}$ rRNA gene. The reaction mixture at a total volume of $20 \mu \mathrm{l}$ consisted of distilled water (DNase-free water) $9.2 \mu 1,10 \mathrm{x}$ HotStar PCR buffer $3.0 \mu 1,25 \mu \mathrm{M} \mathrm{MgCl}_{2} 0.2 \mu 1$, $10 \mu \mathrm{M}$ dNTP mix $0.4 \mu \mathrm{l}, 5 \mathrm{x}$ Q solution $4.0 \mu \mathrm{l}, 10$ $\mu \mathrm{M}$ PCR $2058 \mathrm{~F}$ primer $0.9 \mu 1,10 \mu \mathrm{M}$ PCR $2058 \mathrm{R}$ primer $0.5 \mu 1,10 \mu \mathrm{M}$ PCR $2059 \mathrm{~F}$ primer $0.3 \mu 1$, $10 \mu \mathrm{M}$ PCR 2059R primer $0.8 \mu \mathrm{l}$, and HotStar DNA polymerase $0.3 \mu 1$. A volume of $1 \mu 1$ PCR 1 products were introduced into the mixture as a template. The PCR 2 reaction comprised 35 cycles at predenaturation temperature of $95^{\circ} \mathrm{C}$ for $15^{\prime}$, denaturation at $95^{\circ} \mathrm{C}$ for $30^{\prime \prime}$, annealing at $61^{\circ} \mathrm{C}$ for $30^{\prime \prime}$, elongation at $72^{\circ} \mathrm{C}$ for $1^{\prime}$ and final extension at $72^{\circ} \mathrm{C}$ for $5^{\prime}$. The positive controls used were 194 bp-long positive synthetic DNA controls, which were used in the PCR 2 reaction. The negative controls in the PCR 1 reaction used DNase free water.

The PCR 2 products were subjected to electrophoresis using 3\% agarose. The marker used was the $50 \mathrm{bp}$ marker. The agarose gel was subjected to electrophoresis at 100 volts for 30 minutes, then stained with Gel Red Staining and visualized using $U V$ radiation with the BioRad ${ }^{\circledR}$ GelDoc ${ }^{\mathrm{TM}}$ EZ Imager. The PCR 2 products were shown as bands of $187 \mathrm{bp}, 130 \mathrm{bp}$ and $100 \mathrm{bp}$, respectively.

\section{Statistical analysis}

The collected data were processed with the SPSS software version 20 and Microsoft Excel 
2007. To obtain the significance of the Treponema pallidum multiplex nested PCR test results, sensitivity and specificity were used to evaluate the diagnostic test.

\section{Ethical clearance}

This study obtained ethical clearance from the Health Research Ethics Committee, Faculty of Medicine,Universitas Indonesia, under no. 158/ UN2.F1/ETIK/2015. This study also obtained approval from Cipto Mangunkusumo Hospital (RSCM), the Jakarta One-Door Integrated Service Board (Badan Pelayanan Terpadu Satu Pintu Jakarta), recommendation and research permit from the Jakarta Health Service head office (Dinas Kesehatan Jakarta), and recommendation and research permit from the West Jakarta Health Service sub-office (Suku Dinas Kesehatan Jakarta Barat).

\section{RESULTS}

The collected study sample numbered 122 clinical specimens, consisting of 61 blood specimens and 61 sera from 61 patients with the clinical picture of secondary syphilis. The study subjects were predominantly males with median age of 26 years and overall age range of 18-40 years. A total of $88.5 \%$ (54 study subjects) had a homosexual orientation, i.e. males who had sexual intercourse with males. The majority of study subjects, i.e. $54.10 \%$ (33 of 61 ) had a reactive HIV status (Table 1).
Table 1. Demographic and clinical characteristics of the study subjects $(\mathrm{n}=61)$

\begin{tabular}{ll}
\hline Characteristic & $\mathbf{n ~ ( \% )}$ \\
\hline Sex & $58(95.08)$ \\
Male & $3(4.92)$ \\
Female & \\
Sexual Orientation & $54(88.52)$ \\
$\quad$ Homosexual (MSM) & $6(9.84)$ \\
Heterosexual & $1(1.64)$ \\
Transvestite & $33(54.10)$ \\
Status HIV & $24(39.34)$ \\
Reactive HIV & $4(6.56)$ \\
Nonreactive HIV & \\
No data & $61(100)$ \\
Clinical Manifestation & $11(18.03)$ \\
Maculopapular erythema & $4(6.56)$ \\
Genital ulcer & $3(4.92)$ \\
Moth-eaten Alopecia & $2(3.28)$ \\
Uveitis & \\
Condyloma lata &
\end{tabular}

All sera (61 specimens) were serologically tested for syphilis. A total of 42 of the 61 showed positive results for the RPR and TPHA tests, signifying that the proportion of positives of the serological tests for secondary syphilis in the present study was $68.85 \%$. The Treponema pallidum multiplex nested PCR test was performed for all blood and serum specimens. In blood, the test showed positive results in 14 of 61 specimens $(22.95 \%)$, which were marked by the presence of a $187 \mathrm{bp}$ band on visualization with agarose gel. On the other hand, only 4 of the 61 serum specimens $(6.56 \%)$ were positive.

Figure 1 shows visualization of the PCR test results on agarose as seen under ultraviolet light.

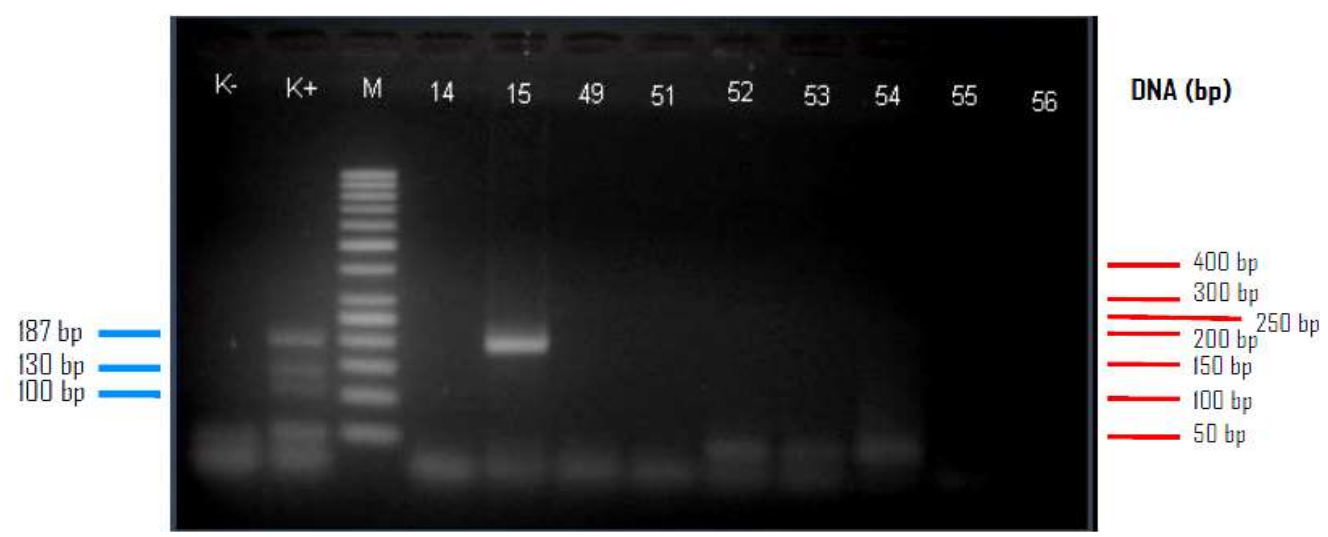

Figure 1. Visualization of positive electrophoresis results band $187 \mathrm{bp}$ specimen no. 15

Treponema pallidum multiplex nested PCR test in blood; $\mathrm{K}-=$ negative control, $\mathrm{K}+=$ positive control, $\mathrm{M}=50$ bp marker; Numbers indicate the numbers of specimen teste 
Table 2. Treponema pallidum multiplex nested PCR test in blood and serological tests of the patients $(\mathrm{n}=61)$

\begin{tabular}{llccc}
\hline & & \multicolumn{2}{c}{ Serological test } & \multirow{2}{*}{ Total } \\
\cline { 3 - 4 } & & Positive & Negative & \\
\hline $\begin{array}{l}\text { T.pallidum multiplex nested PCR } \\
\text { blood }\end{array}$ & Positive & 13 & 1 & 14 \\
\hline Total & Negative & 29 & 18 & 47 \\
\hline
\end{tabular}

The results of the Treponema pallidum multiplex nested PCR test using blood and serum were compared with the results of the serological tests. The proportion of positives of the Treponema pallidum multiplex nested PCR test using blood was $22.95 \%$, compared with the proportion of positives of the serological tests of $68.85 \%$. Nearly all patients with positive blood results on the Treponema pallidum multiplex nested PCR test had positive serological test results. There was one patient (5.26\%) whose blood test result on multiplex nested PCR was positive, but whose serological test results did not support secondary syphilis (RPR titer $>1: 8$ and TPHA titer $\leq 1: 80$ ). The proportion of positives in the Treponema pallidum multiplex nested PCR test for serum was $6.56 \%$ compared with the positive serological test results of $68.85 \%$. All patients' sera with positive Treponema pallidum multiplex nested PCR test results also had serological test results that supported secondary syphilis.

Treponema pallidum multiplex nested PCR for blood showed a sensitivity of $30.95 \%$ and a specificity of $94.7 \%$ (Table 2), while for serum the test showed a sensitivity of $9.52 \%$ and a specificity of $100 \%$ (Table 3 ).

Under the conditions of the Treponema pallidum multiplex nested PCR test in this study, it was found that the test for blood was able to detect Treponema pallidum 3.25 times higher positive serological test results, compared with serum, and statistically showed a significant difference.

\section{DISCUSSION}

The study subjects were predominantly males, particularly the homosexuals, i.e. male who had sex with males (MSM). According to the results of a survey by the Integrated Surveillance of Behavioral Biology program (Surveilans Terpadu Biologi Perilaku, STBP) in 2011 in 23 large Indonesian cities, the highest prevalence of syphilis was in the transvestite group, but the MSM were the most at risk population group for infection with syphilis. ${ }^{(3)}$ If compared with the STBP surveys of 2007 and 2011, the prevalence of syphilis increased 3-fold in the MSM population. ${ }^{(3)}$ The increased prevalence of syphilis in the MSM group had also been reported by several studies in developed countries. ${ }^{(17)}$

The Treponema pallidum multiplex nested PCR test using blood was able to detect Treponema pallidum at $22.95 \%$. The proportion of positives of the test using blood was lower than in other studies. The Treponema pallidum PCR test using blood has been evaluated in several studies. ${ }^{(8,18)}$ The proportion of positives of the PCR tests vary among a number of

Table 3. Treponema pallidum multiplex nested PCR test in serum and serological tests of the patients $(\mathrm{n}=61)$

\begin{tabular}{llccc}
\hline & & \multicolumn{2}{c}{ Serological test } & \multirow{2}{*}{ Total } \\
\cline { 3 - 4 } & & Positive & Negative & \\
\hline $\begin{array}{l}\text { T.pallidum multiplex nested PCR } \\
\text { blood }\end{array}$ & Positive & 4 & 0 & 4 \\
\hline Total & Negative & 38 & 19 & 57 \\
\hline
\end{tabular}


studies on patients with secondary syphilis, which comprise the studies conducted by Martin et al., ${ }^{(18)}$ Tipple et al. ${ }^{(8)}$ and Grange et al. ${ }^{(10)}$ with a proportion of positives of $44 \%, 58 \%$ and $38 \%$, respectively. In these studies the PCR test with the target gene PolA resulted in the detection of Treponema pallidum using blood in patients with reinfection of syphilis, primary syphilis, secondary syphilis, and latent syphilis. In metaanalytic studies, the sensitivity of PCR tests using blood in patients with secondary syphilis reached $52.2 \%{ }^{(19,20)}$

The Treponema pallidum multiplex nested PCR test performed on serum could detect Treponema pallidum at $6.56 \%$. The proportion of positives of the Treponema pallidum multiplex nested PCR test using serum was lower than in other published studies. The study by Gayet-Ageron et al. ${ }^{(15)}$ and Grange et al. ${ }^{(10)}$ found that the sensitivity of serum examination in secondary syphilis was $47 \%$ and $15 \%$, respectively. Both studies used the same target gene tpp 47.

The difference in the proportion of positives in the Treponema pallidum multiplex nested PCR test using blood and serum with the other studies may presumably have been caused by the different target genes used, the PCR method, the sample preparation, the active phase of the disease, and the presence of immunodeficiency. The use of the Treponema pallidum target gene and the differing clinical specimens affected the results of the multiplex nested PCR..$^{(13,14,21)}$ The target gene and PCR method used in this study refers to the target gene and PCR method used by Gultom et al. ${ }^{(16)}$ The study by Gayet-Ageron et al. ${ }^{(20)}$ used the $47 \mathrm{kDa}$ Treponema pallidum target gene with the real-time PCR method. The study by Grange et al. ${ }^{(10)}$ used the tpp 47 Treponema pallidum target gene with the nested PCR method. In the meta-analytic study by Gayet-Ageron et al. ${ }^{(9)}$ that compared the use of the target genes tpp 47 and polA, the investigators stated that the most used target gene in molecular studies of Treponema pallidum is the tpp47 gene $(78 \%)$. From the results of the comparison it was apparent that both target genes, the tpp47 as well as the polA gene showed the same accuracy. There have been no previous publications on the use of the 23S rRNA target gene to detect Treponema pallidum in molecular PCR tests.

Spirochetemia may be detected in the blood particularly in the active phase. In the course of syphilis the highest concentration of bacteria are found in the secondary stage. ${ }^{(22)}$ In the present study, the low number of Treponema pallidum detected with multiplex nested PCR, was presumably because the concentration of Treponema pallidum in the blood of the patients were below the detection threshold of the PCR test or there was DNA damage in the specimens that were not immediately processed.

The presence of immunodeficiency in the patients will affect the proportion of positives of the Treponema pallidum multiplex nested PCR test. ${ }^{(23)}$ In this study the majority of the patients showed reactive HIV results (54.09\%). The PCR test successfully detected Treponema pallidum in one patient with reactive HIV, the RPR test results showed a high titer (1:16 to $1: 64)$, but the TPHA test yielded a low titer $(1: 20$ to $1: 80)$. This patient was diagnosed as having syphilis with the serological tests, which needs to be confirmed. In patients with reactive HIV, the immune response may be suppressed so that the formation of antitreponemal antibodies is inhibited. As a result, the TPHA test shows a low or negative titer. ${ }^{(23,24)}$ In contrast, the condition of immunodeficiency causes a reduction in the numbers and ability of the macrophages to eliminate pathogenic bacteria, so that the number of Treponema pallidum may be higher in the blood circulation, particularly in the active phase of syphilis. ${ }^{(22)}$ High spirochetemia will increase the sensitivity of the PCR. In the present study, the majority of patients who showed positive results for the Treponema pallidum multiplex nested PCR test both in blood and serum had a reactive HIV status.

The purpose of the Treponema pallidum PCR test is to detect Treponema pallidum DNA. 
Various specimens may be used for the PCR test, but not all specimens have the same diagnostic value. The differing processes in the blood and serum may presumably cause differences in the numbers of bacteria that are present. In the blood, all blood components are preserved and Treponema pallidum exists in greatest numbers. In serum, there is separation of the cellular components from the liquid as a result of the centrifugation process. Treponema pallidum may most probably be precipitated together with the cellular components, so that the number of Treponema pallidum in serum is not as great as in the blood. This is thought to be the cause of the higher proportion of positives of the Treponema pallidum multiplex nested PCR test in the blood as compared with serum.

Based on the published results of a metaanalysis, the highest sensitivity of the Treponema pallidum PCR of $78.40 \%$ was obtained from the examination of smears of lesions in primary syphilis. ${ }^{(23)}$ In examinations using blood samples the sensitivity of PCR in primary and secondary syphilis was moderate. ${ }^{(15,20)}$ The low proportion of positives in the Treponema pallidum PCR test shows that the PCR test should not be used to rule out the diagnosis of syphilis in patients with the clinical picture of secondary syphilis. The PCR test is more useful as a confirmatory test, particularly in serological testing with dubious results. ${ }^{(20)}$

In specimens with positive serological test results, the sensitivity of the Treponema pallidum multiplex nested PCR test using blood was $30.95 \%$, whereas when using serum, the sensitivity of Treponema pallidum multiplex nested PCR test was only $9.52 \%$. The results of this study are supported by the study conducted by Grange et al. ${ }^{(10)}$ who found proportions of positives of serum and blood of $15 \%$ and $38 \%$, respectively, in the PCR test for Treponema pallidum in patients with secondary syphilis.

One of the limitations in this study was the fact that no microscopic examination was performed as gold standard for the diagnosis of syphilis for comparison with the multiplex nested PCR test, due to the difficulties in collecting exudates from lesions of syphilis in all patients.

The study was able to show the best specimens between blood and serum of patients with the clinical picture of secondary syphilis for the Treponema pallidum multiplex nested PCR test with the 23S rRNA target gene to assist clinicians in determining the diagnosis and instituting rapid and appropriate management.

Further studies are required using molecular tests with different target genes and PCR methods for blood with positive serological test results, to explain the low proportion of positives in the Treponema pallidum multiplex nested PCR test.

\section{CONCLUSIONS}

The sensitivity of the Treponema pallidum multiplex nested PCR test using blood specimens is 3.25 times higher than using serum, i.e. $30.95 \%$ compared with $9.52 \%$. In patients with the clinical picture of secondary syphilis, using blood is better than using serum for the Treponema pallidum multiplex nested PCR test.

\section{CONFLICT OF INTEREST}

Competing interests: no relevant disclosures.

\section{ACKNOWLEDGEMENT}

This study was funded by Hibah PUPT of the Directorate of Higher Education (Dikti) 20152016. We thank the Department of Microbiology, Faculty of Medicine University of Indonesia (FKUI) and Department of Dermatoveneorology, Faculty of Medicine University of Indonesia Cipto Mangunkusumo Hospital (FKUI-RSCM), STD Clinic Cipto Mangunkusumo Hospital, STD Clinic Puskesmas Pasar Rebo, STD Clinic Puskesmas Tambora and PKBI Pro Care Clinic Jatinegara for all assistance and cooperation in this study. 


\section{CONTRIBUTORS}

IE, YR, and AY designed the study. AY and WI supervised fieldwork and gathered data and samples. IE and WI did statistical analyses. IE, YR and AY wrote the first draft of the report, with revisions and input from WI. All authors contributed to revisions and approved the final version.

\section{REFERENCES}

1. Wijesooriya NS, Rochat RW, Kamb ML, et al. Global burden of maternal and congenital syphilis in 2008 and 2012: a health systems modelling study. Lancet Glob Health 2016;4:e525-33.

2. Braxton J, Carey D, Davis D, et al. Sexually transmitted disease surveillance 2014. Atlanta, Georgia: U.S. Department of Health and Human Services, Centers for Disease Control and Prevention National Center for HIV/AIDS, Viral Hepatitis, STD, and TB Prevention Division of STD Prevention; 2015.

3. Kementerian Kesehatan Republik Indonesia. Surveilans terpadu biologi perilaku. Jakarta: Kementerian Kesehatan Republik Indonesia Dirjen Pengendalian Penyakit dan Penyehatan Lingkungan; 2011.

4. World Health Organization. Global incidence and prevalence of selected curable sexually transmitted infections-2008. Geneva: World Health Organization;2012.

5. World Health Organization. Report on global sexually transmitted infection surveillance 2013. Geneva: World Health Organization;2014.

6. Tramont EC. Treponema pallidum (syphilis). In: Bennett JE, Dolin R, Blaser MJ, editors. Mandell, Douglas, and Bennett's principles and practice of infectious diseases. Philadelphia: Elsevier Saunders;2015.p.3035-55.

7. Zobaníkova M, Mikolka P, Čejková D, et al. Complete genome sequence of Treponema pallidum strain DAL-1. Standards Genomic Sci 2012;7:12-21. DOI:10.4056/sigs.2615838.

8. Tipple C, Hanna MOF, Hill S, et al. Getting the measure of syphilis: qPCR to better understand early infection. Sex Transm Infect 2011;87:e485. doi: 10.1136/sti.2011.049494.

.9 Gayet-Ageron A, Combescure C, Lautenschlager $\mathrm{S}$, et al. Comparison of the diagnostic accuracy of polymerase chain reaction targeting the $47 \mathrm{kDa}$ protein membrane gene of Treponema pallidum or the DNA polymerase I gene: a systematic review and meta-analysis. J Clin Microbiol 2015; 53:3522-9. doi: 10.1128/JCM.01619-15.

10 Grange PA, Gressier L, Dion PL, et al. Evaluation of a PCR test for detection of Treponema pallidum in swabs and blood. J Clin Microbiol 2012;50:54652. doi: 10.1128/JCM.00702-11.

11 Casal CAD, Silva MOD, Costa IB, et al. Molecular detection of Treponema pallidum sp. pallidum in blood samples of VDRL-seroreactive women with lethal pregnancy outcomes: a retrospective observational study in northern Brazil. Revista da Sociedade Brasileira de Medicina Tropical 2011;44:451-6.

12. Buffet M, Grange PA, Gerhardt P, et al. Diagnosing Treponema pallidum in secondary syphilis by PCR and immunohistochemistry. J Invest Dermatol 2007;127:2345-50. doi: 10.1038/ sj.jid.5700888.

13 Cruz AR, Pillay A, Zuluaga AV, et al. Secondary syphilis in Cali, Colombia: new concepts in disease pathogenesis. PLoS Negl Trop Dis 2010;4:e690. doi: 10.1371/journal.pntd.0000690.

14 Ho EL, Lukehart SA. Syphilis: using modern approaches to understand an old disease. J Clin Invest 2011;121:4584-92.

15 Gayet-Ageron A, Toutus-Trelllu NBL, Lautenschlager S, et al. Assessment of a real-time PCR test to diagnose syphilis from diverse biological samples. Sex Transm Infect 2009;85:2649. doi: 10.1136/sti.2008.034314.

16. Gultom DA, Rosana Y, Efendi I, et al. Detection and identification of azithromycin resistance mutations on Treponema pallidum 23S rRNA gene by nested multiplex polymerase chain reaction. Med J Indones 2017;26:90-6. https://doi.org/ 10.13181/mji.v26i2.1543.

17. Sharma S, Chaudhary J, Hans C. VDRL v/s TPHA for diagnosis of syphilis among HIV sero-reactive patients in a tertiary care hospital. Int J Curr Microbiol App Sci 2014;3:726-30.

18. Martin IE, Tsang RSW, Sutherland K, et al. Molecular characterization of syphilis in patients in Canada: azithromycin resistance and detection of Treponema pallidum DNA in whole-blood samples versus ulcerative swabs. J Clin Microbiol 2009;47:1668-73.

19. Tipple C, Jones R, McClure M, et al. Rapid Treponema pallidum clearance from blood and ulcer samples following single dose benzathine penicillin treatment of early syphilis. PLoS Negl Trop Dis 2015;10:e0003492. doi: 10.1371/journal. pntd. 0003492 .

20. Gayet-Ageron A, Lautenschlager S, Ninet B, et al. Sensitivity, specificity and likelihood ratios of PCR in the diagnosis of syphilis: a systematic 
review and meta-analysis. Sex Transm Infect 2013;89:251-6.

21. Sato NS. Laboratorial diagnosis of syphilis. Syphilis - recognition, description and diagnosis. Croatia: INTECH;2011.p.87-108.

22. Wu BR, Tsai MS, Yang CJ, et al. Spirochetemia due to Treponema pallidum using polymerasechain-reaction assays in patients with early syphilis: prevalence, associated factors and treatment response. Clin Microbiol Infect 2014;20:O524-7. doi: 10.1111/1469-0691.12504.
23. Leslie DE, Azzato F, Karapanagiotidis T, et al. Development of a real-time PCR assay to detect Treponema pallidum in clinical sspecimens and assessment of the assay's performance by comparison with serological testing. J Clin Microbiol200745:93-6. doi:10.1128/JCM.01578-06. 